\title{
Infection Rate of Tunneled Hemodialysis Catheters
}

\author{
Tünelli Hemodiyaliz Kateterlerinin Enfeksiyon Oranları
}

\author{
Ata Niyazi ECEVIT ${ }^{1}$ \\ (1) 0000-0002-8820-9305 \\ Okay Güven KARACA ${ }^{1}$ \\ (D) 0000-0002-7749-9706 \\ Mehmet KALENDER ${ }^{2}$ \\ (D) 0000-0002-8984-4028 \\ Osman Tansel DARÇIN ${ }^{3}$ \\ (1) 0000-0002-8148-8516
}

\begin{abstract}
Aim: Tunneled hemodialysis catheters are frequently used for hemodialysis patients and provide temporary venous access. However, it causes complications such as catheter-related infection, pneumothorax and hematoma. In this study, we aimed to evaluate the infections, complications and catheter patency rates that developed after the use of tunnel catheters connected to three different access routes.

Material and Methods: A total of 145 patients who underwent hemodialysis due to chronic renal failure and who were placed on permanent hemodialysis catheter were included. In this study, jugular vein route was used as the first choice for the dialysis access route, when other access routes were needed due to complications and infection, femoral vein route was the second choice, while subclavian vein route was the third choice.

Results: The femoral vein group had the highest infection rate and the lowest patency rate (both $\mathrm{p}<0.001$ ). The infection rate at the end of one year was $65.3 \%, 95.6 \%$, and $64.0 \%$ for the jugular vein, femoral vein and subclavian vein, respectively. At the end of one year, patency rates for the jugular vein, subclavian vein and femoral vein were $57.3 \%, 6.7 \%$, and $32.0 \%$,

Conclusion: Although the jugular vein is the first choice for venous entry in hemodialysis patients, femoral and subclavian veins are also used. In this study, the jugular vein was the best option in terms of patency rate and infection. The femoral vein, on the other hand, had the worst patency rate and was also the access route with the highest infection rate.
\end{abstract}

${ }^{1}$ Ankara City Hospital Cardiovascular respectively.

Surgery Clinic, Ankara, Turkey

${ }^{2}$ Kocaeli Derince Training and Research Hospital Cardiovascular Surgery Clinic, Kocaeli, Turkey

${ }^{3}$ Antalya Training and Research Hospital Cardiovascular Surgery Clinic, Antalya, Turkey

\section{Corresponding Author Sorumlu Yazar \\ Ata Niyazi ECEVİT \\ drataecevit@gmail.com}

Received / Geliş Tarihi : 26.01.2021

Accepted / Kabul Tarihi : 22.03.2021

Available Online /

Çevrimiçi Yayın Tarihi : 07.04.2021
Keywords: Hemodialysis; infection; catheter.

\section{öz}

Amaç: Tünelli hemodiyaliz kateterleri hemodiyaliz hastaları için sıklıkla kullanılır ve hastalara hemodializ için geçici venöz erişim sağlar. Ancak kateter ile ilişkili enfeksiyon, pnomotoraks ve hematom gibi komplikasyonlara neden olur. Bu çalışmada, üç farklı giriş yoluna bağlı tünelli kateterlerin enfeksiyon, komplikasyon ve açıklık oranlarının değerlendirilmesi amaçlanmıştır.

Gereç ve Yöntemler: Çalışmaya kronik böbrek yetmezliği nedeniyle hemodiyaliz yapılan ve kalıcı hemodiyaliz kateteri takılan toplam 145 hasta dahil edildi. Bu çalışmada diyaliz giriş yolu olarak juguler ven yolu ilk tercih olarak kullanıld, komplikasyonlar ve enfeksiyona bağlı olarak diğer giriş yollarına ihtiyaç duyulduğunda femoral ven yolu ikinci tercih olurken subklavian ven yol ise üçüncü tercih oldu.

Bulgular: Femoral ven grubu en yüksek enfeksiyon oranına ve en düşük açıklık oranına subklavyen vende sirasiyla $\% 65,3 ; \% 95,6$ ve $\% 64,0$ idi. Birinci y1l sonunda juguler ven, subklavyen ven ve femoral ven açıklık oranları ise sırasıyla $\% 57,3 ; \% 6,7$ ve $\% 32,0$ idi.

Sonuç: Hemodiyaliz hastalarında juguler ven venöz giriş için ilk seçenek olmasına rağmen femoral ve subklavyen venler de kullanılmaktadır. Bu çalışmada, juguler ven açıklık oranı ve enfeksiyon açısından en iyi seçenek idi. Diğer taraftan, femoral ven ise en kötü açıklık oranına sahipti ve aynı zamanda enfeksiyon oranı en yüksek olan giriş yolu idi.

Anahtar kelimeler: Hemodiyaliz; enfeksiyon; kateter. sahipti (her iki $\mathrm{p}<0.001$ ). Birinci y1lın sonunda enfeksiyon oranı juguler ven, femoral ven ve 


\section{INTRODUCTION}

The number of patients in need of hemodialysis due to chronic kidney failure increases with the development of technology and the health system (1). For chronic hemodialysis patients, the best route of entry for hemodialysis is primarily arteriovenous fistula (AVF), as indicated in more than one guideline $(2,3)$. However, during AVF maturation process or in cases where there is no suitable vessel, alternative access ways are preferred. Tunneled hemodialysis catheter (THC) is a good alternative in this group of patients for hemodialysis. It is previously shown that less than $10 \%$ of hemodialysis patients begin hemodialysis with an indwelling catheter, as recommended by guidelines $(2,3)$.

THC are usually placed in the rib cage through a central vein. Mostly, the internal jugular vein is used. Less frequently, and the subclavian or femoral vein is used if it's thought that jugular vein is hard to access. The femoral vein is used when bilateral occlusion occurs in the jugular and subclavian veins due to prolonged use in upper extremity veins (4). THC provide temporary venous intervention for hemodialysis patients until the AVF or polyfluoroethylene graft is ready after maturation, but it should always be in mind that catheter may cause infection complications. Infections are serious complications for THC. Catheter-related infection is on average $0.2-0.4 \%$ patient/day and the equivalent of 0.7-1.5 catheter per year in a prior study (5). Catheter-related bacteremia can result in endocarditis, osteomyelitis, epidural abscess, septic arthritis, and death (6).

In this study, we aimed to evaluate the infection and catheter-related complications, and patency rates for the three different ways of THC.

\section{MATERIAL AND METHODS}

Our study, which was taken with the approval of the Ethics Committee of Selçuk University Faculty of Medicine (07.01.2014, 1/16), was designed as a retrospective study. A total of 145 patients who underwent hemodialysis due to chronic renal failure and who were placed on permanent hemodialysis catheter were included in the study.

The internal jugular vein was the primarily venous access route chosen for the patients. The femoral vein was preferred as the second choice when a new access route was needed for certain reasons such as catheter thrombosis and infection. The subclavian vein was our third choice for this catheter.

The procedures were carried out by cardiovascular surgeons, using standard surgical area cleaning, with the guide of ultrasonographic visualization. $24 \mathrm{~cm} \mathrm{12-14}$ French size permanent hemodialysis catheter was used for internal jugular vein and subclavian vein, while $36-42 \mathrm{~cm}$ catheter was used for femoral route. We routinely confirmed place of each catheter by direct radiography or ultrasonography with the inserted internal jugular catheter was in the right atrium and the femoral catheter in the proximal inferior cava. Catheters were immediately flushed with heparinized saline before use.

In the follow-up of the patients, when there were signs of fever and chills, blood and catheter cultures were taken for bacteriological analysis from the patients. Antibiotic treatment and catheter replacement were considered according to the laboratory results.

\section{Statistical Analysis}

The normality assumption was examined with Kolmogorov-Simirnov test. Comparisons between groups were made using One-Way ANOVA followed by LSD post hoc test or Kruskal-Wallis followed by Dunn's post hoc test. Pearson chi-square or Fisher-Freeman-Halton test was used to analyze categorical variables. Numerical variables were summarized as mean \pm standard deviation or median, interquartile range, minimum-maximum, while categorical variables were summarized with frequency and percentage. Infection free survival and patency rates were analyzed by using life tables and Kaplan-Meier survival analysis, and the Log-rank test was used to compare groups. Statistical analyses were performed with SPSS v.22 statistical package and 0.05 was considered as the statistical significance level.

\section{RESULTS}

Of the patients $76(52.4 \%)$ were male and $69(47.6 \%)$ were female. The mean age of the patients was $52.48 \pm 9.83$ years. There were $75(51.7 \%)$ patients in internal jugular vein group, while $45(31.0 \%)$ patients in subclavian vein and $25(17.2 \%)$ patients in femoral vein groups. There was no significant difference in terms of gender, age, hypertension, diabetes mellitus, and congestive heart failure between the jugular vein access, the subclavian vein and femoral vein access patients (Table 1). Patients with internal jugular vein catheters underwent hemodialysis for a median of 1 year, while patients who were placed hemodialysis catheters through femoral and subclavian veins were on hemodialysis for median of 4 and 3 years, respectively $(\mathrm{p}<0.001)$. When the patients were examined in terms of postoperative complications, pneumothorax developed in $1(1.3 \%)$ patient in the internal jugular vein group and $2(8.0 \%)$ in the subclavian vein group after the insertion of central hemodialysis catheter (Table 2). There was no significant difference between the groups in terms of pneumothorax $(\mathrm{p}=0.105)$. Hemothorax developed only in $1(4.0 \%)$ patient in the subclavian catheter group. Hematoma development was seen in 7 patients, $4(5.3 \%)$ in the internal jugular vein group and $3(6.7 \%)$ in the femoral vein group. However, there was no significant difference between the groups in terms of both hemothorax and hematoma formation $(\mathrm{p}=0.172$ and $\mathrm{p}=0.524$, respectively). There were 6 patients with misdirection in total, whom $4(5.3 \%)$ were in internal jugular vein group while $2(8.0 \%)$ of them in subclavian vein group. Interestingly, all internal jugular misdirected catheters were inserted via the left jugular vein. But there was no significant difference between groups $(\mathrm{p}=0.252)$.

Considering the infection rates of the groups, the possibility of developing an infection at the end of 1 year was $65.3 \%(n=49), 95.6 \%(n=43)$, and $64.0 \%(n=16)$ in the jugular vein, femoral vein and subclavian vein, respectively. Infection development rate at the end of first year was highest in the femoral vein group and it was statistically significantly higher than other two groups $(\mathrm{p}<0.001)$. Infection free survival in femoral vein group was significantly lower in comparison to internal jugular vein and subclavian vein groups (Table 3, Figure 1). On the other hand, although the jugular and subclavian groups were close in terms of the risk of developing an infection, the jugular group was slightly better in freedom from infection. At the end of one year, patency rates of the 
jugular vein, subclavian vein and femoral vein were $57.3 \%$ $(n=43), 6.7 \%(n=3)$, and $32.0 \%(n=8)$, respectively. There was a statistically significant difference between the groups in terms of patency $(\mathrm{p}<0.001)$. The lowest patency rate was in the femoral vein group, at the end of first year, with $6.7 \%$. On the other hand, the jugular vein group had the best patency with $57.3 \%$. Accordingly, patency survival in femoral vein group was found significantly lower than internal jugular vein and subclavian vein groups (Table 3, Figure 2). Bacteriological cultures revealed, methicillin-resistant Staphylococcus aureus, Enterococcus and Pseudomonas species, and patients were treated with cephalosporin (e.g., ceftazidime, cefepime) or aminoglycoside according to our antibiotic regime.

Table1. Preoperative patient characteristics

\begin{tabular}{lcccc}
\hline & Internal Jugular Vein $(\mathbf{n = 7 5})$ & Femoral Vein $(\mathbf{n = 4 5})$ & Subclavian Vein $(\mathbf{n = 2 5})$ & $\mathbf{p}$ \\
\hline Age (years), mean \pm SD & $51.61 \pm 10.02$ & $52.51 \pm 10.55$ & $55.00 \pm 7.53$ & 0.331 \\
Male, n (\%) & $39(52.0)$ & $23(51.1)$ & $14(56.0)$ & 0.921 \\
DM, n (\%) & $25(33.3)$ & $13(28.9)$ & $7(28.0)$ & 0.823 \\
HT, $(\%)$ & $19(25.3)$ & $10(22.2)$ & $7(28.0)$ & 0.857 \\
CAD, n (\%) & $13(17.3)^{\mathrm{a}}$ & $0(0.0)^{\mathrm{b}}$ & $0(0.0)^{\mathrm{b}}$ & $\mathbf{0 . 0 0 2}$ \\
Obesite, $\mathbf{n}(\%)$ & $11(14.7)$ & $6(13.3)$ & $3(12.0)$ & 0.940 \\
CHF, n (\%) & $6(8.0)$ & $3(6.7)$ & $2(8.0)$ & 0.116 \\
Years on HD (years), & $1(1)[1-3]^{\mathrm{a}}$ & $4(2)[2-7]^{\mathrm{b}}$ & $3(1)[2-4]^{\mathrm{c}}$ & $<\mathbf{0 . 0 0 1}$ \\
median (IQR) [min-max] &
\end{tabular}

DM: diabetes mellitus, HT: hypertension, CAD: coronary artery disease, CHF: congestive heart failure, SD: standard deviation, IQR: interquartile range, ${ }^{\text {a,b,c }}$ : different superscript letters denote significant difference between groups according to the post hoc test result

Table 2. Postoperative complications

\begin{tabular}{lcccc}
\hline & Internal Jugular Vein $(\mathbf{n}=\mathbf{7 5})$ & Femoral Vein $(\mathbf{n}=\mathbf{4 5})$ & Subclavian Vein $(\mathbf{n}=\mathbf{2 5})$ & $\mathbf{p}$ \\
\hline Pneumothorax, $\mathbf{n}(\%)$ & $1(1.3)$ & $0(0.0)$ & $2(8.0)$ & 0.105 \\
Hemothorax, $\mathbf{( \% )}$ & $0(0.0)$ & $0(0.0)$ & $1(4.0)$ & 0.172 \\
Hematoma, $\mathbf{( \% )}$ & $4(5.3)$ & $3(6.7)$ & $0(0.0)$ & 0.524 \\
Misdirection, $\mathbf{n}(\%)$ & $4(5.3)$ & $0(0.0)$ & $2(8.0)$ & 0.252 \\
\hline
\end{tabular}

Table 3. Patency and infection free survival in groups (day)

\begin{tabular}{|c|c|c|c|c|}
\hline & Internal Jugular Vein $(n=75)$ & Femoral Vein $(n=45)$ & Subclavian Vein $(n=25)$ & $\mathbf{p}$ \\
\hline fection Free Survival & & & & \multirow{3}{*}{$<0.001$} \\
\hline $\mathrm{Mec}$ & $5.9(199.1-300.9)$ & $70.0 \pm 23.5(23.9-116.0)$ & $240.0 \pm 24.9(191.0$ & \\
\hline Mean \pm SE $(95 \% \mathrm{CI})$ & 232. & 11 & $216.8 \pm 26.4$ & \\
\hline \multicolumn{5}{|l|}{ Patency } \\
\hline $\begin{array}{l}\text { Median } \pm \text { SE }(95 \% \mathrm{CI}) \\
\text { Mean } \pm \text { SE }(95 \% \mathrm{CI})\end{array}$ & $262.8 \pm 14.9(233.5-292.1)$ & $\begin{array}{c}70.0 \pm 23.5(23.9-116.0) \\
118.7 \pm 15.4(88.5-149.0)\end{array}$ & $\begin{array}{l}240.0 \pm 33.3(174.7-305.3) \\
217.6 \pm 25.8(167.0-268.1)\end{array}$ & $<0.001$ \\
\hline
\end{tabular}

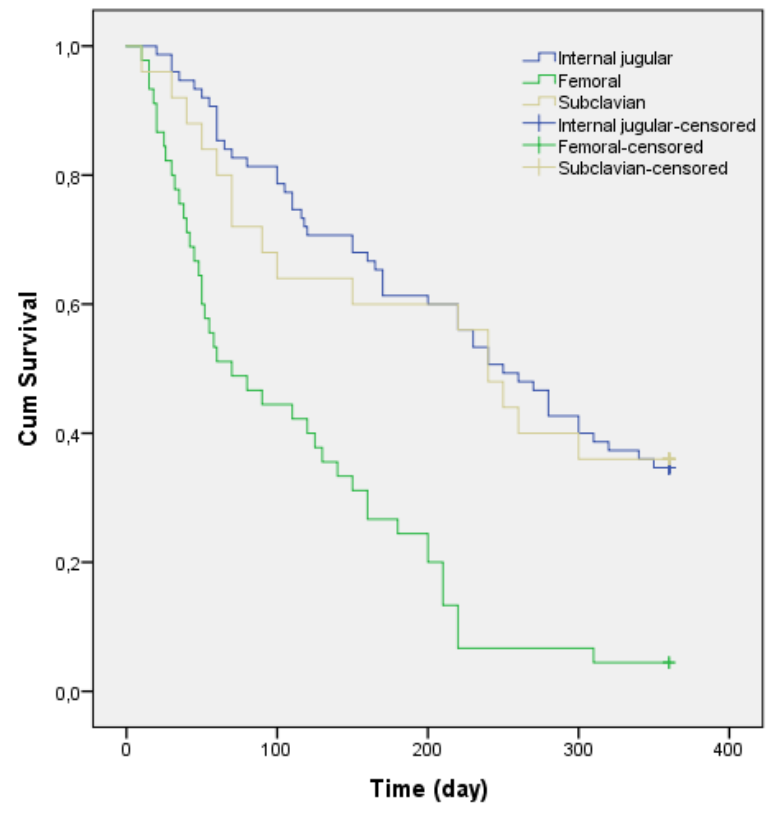

Figure 1. Infection free survival in groups

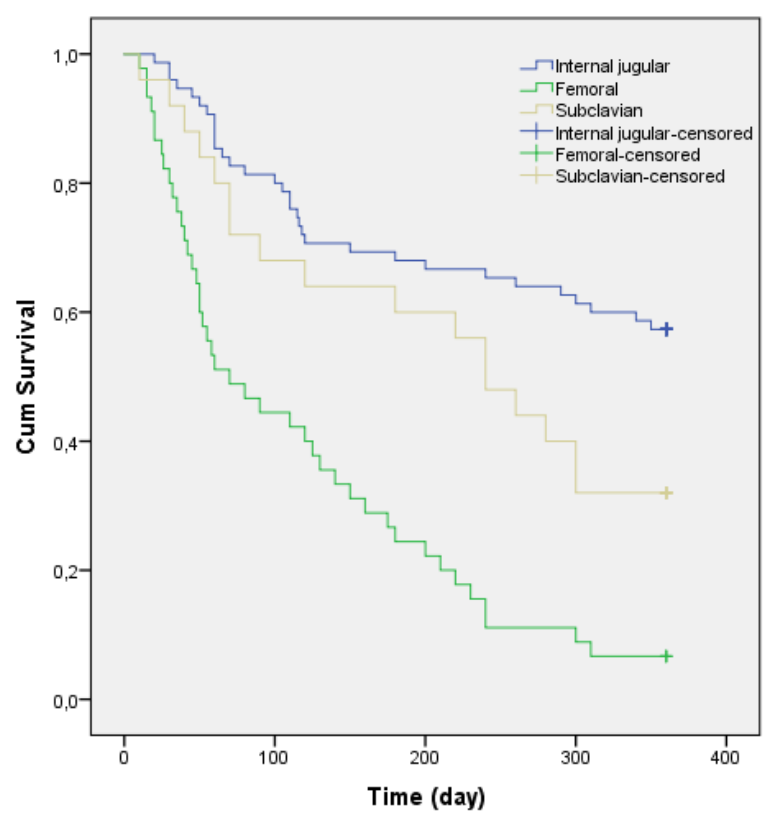

Figure 2. Patency rates in groups 


\section{DISCUSSION}

Dialysis access is the most important problem in patients with chronic kidney failure. An AVF is still the most valid access route, but this is not always possible in practice. $\mathrm{THC}$ is required in patients who are on dialysis for a long time or expected maturation of the fistula. The Kidney Disease Outcomes Quality Initiative (K/DOQI) practice guidelines mandate standards for dialysis access and maintenance (2-3). The current K/DOQI guidelines recommend that $50 \%$ of all new accesses for hemodialysis be natural vein fistulas, with a goal prevalence of $4 \%$ fistulas throughout the dialysis population in the United States (2-3). THC remains an integral tool both as a bridge for fistula maturation and as the sole venous access to achieve this goal in a select population of patients.

A sudden deterioration in the general condition of the patient after a central venous catheter should suggest a complication (7). Complications related to tunneled dialysis catheters may cause various problems. These complications are also important in terms of patients and treatment compliance in complications related to the preferred access routes. These are pneumothorax, hemathorax, hematoma, infections, catheter dysfunction, arterial puncture, arterialvenous fistula, nerve injury, thoracic duct injury (left side only), venous air embolism, intraluminal dissection, and puncture of the aorta and central vein stenosis $(8,9)$. Diagnostic procedures, including a bedside ultrasound, transesophageal echocardiography, or vascular computed tomography, and the execution of fast and necessary management procedures can save the patient's life (10). Serious complications play an important role in mortality and morbidity. Complications also cause a significant increase in treatment cost.

Pneumothorax is one of the common complications after THC (9). The incidence of pneumothorax after central catheter insertion varies between 1 and $6 \%$ (11). Chest radiography and ultrasonography can be used in the diagnosis of pneumothorax (9). In our study, pneumothorax was seen in only 3 patients and there was no significant difference between the groups. Subclavian vein insertion has been reported to have a higher pneumothorax incidence of than other veins insertion (12). In our patients, pneumothorax was more common in the subclavian vein, but there was no significant difference with the jugular vein. When a pneumothorax develops, the size, symptoms, spontaneous use of breathing or mechanical ventilation, and clinical diagnosis of tension pneumothorax affects the treatment strategy. Treatment options include: observation, outpatient insertion of a Heimlich valve, and inpatient tube thoracostomy (13). We were content with just observing our patients.

Hemothorax occurs as a result of vascular injury. Arterial puncture, venous perforation/laceration, myocardial injury, and associated hemorrhage and hematoma (hemopericardium, hemothorax, hemomediastinum) also occur due to vascular injury (14). Hematoma formation has been reported in variable manner, about $0 \%$ to $4.7 \%$ of all catheter placements $(15,16)$. Hematorax occurred in only 1 patient, however, hematoma appeared in a total of 7 patients in our study. Catheter placement sites may leak for variable periods, although there is a much higher risk for patients with hematological malignancies, coagulopathies, thrombocytopenia, or heparin use.
A lesser known but important complication of central venous catheter insertion is the misplacement of the tip of the central venous catheter in a vein other than the central vein. Misdirection has been described in the literature in approximately $7 \%$ of thoracic central venous catheter insertion cases and can lead to serious complications indeed (17). Misdirection of subclavian vein catheters increases the risks of catheter dysfunction, catheter wedging, local venous thrombosis, erosion or perforation of vessel walls, and cranial retrograde injection (18). A higher incidence of malpositioning in the left thoracic venous system compared to the right side has been reported. As stated by Liberek at al. (19), incorrect catheter orientation can also be seen in patients with permanent left superior vena cava.

The right side of the circulation should be considered the first choice for central venous catheter insertion, unless the right side insertion sites are contraindicated. Chest pain may be associated with infusion via a central venous catheter that is misplaced into small branches of major central vessels. Retrosternal pain radiating to the back by infusion of fluid into the left internal mammary vein has been reported in numerous case series (20). In our study, only 6 patients had catheter malposition, 4 of them were inserted into the jugular vein, 2 of them were placed in the subclavian vein. In most cases, if a catheter is positioned incorrectly, the priority should be to reposition, replace, or remove it as soon as possible $(21,22)$. In our patients, a new catheter was inserted after partial retraction and redirection of the wire guide, which could correct the mispositioning.

Catheter related infections are the most common and actually the most frightening complications. The incidence of catheter-related bacteremia has been reported in most studies from 2.5 to 5.5 episodes/1000 catheter days $(23,24)$ Factors for catheter related infections include previous bacteremia attacks, advanced age, diabetes, malnutrition, iron overload, longer catheter use, and peripheral atherosclerosis (25). In addition, other factors specific to hemodialysis related catheter infections include the frequent use of catheters, contamination of dialysis solutions, and colonization with bacteria (26). Good catheter and exit site care with body material isolation and prophylactic topical antibiotics reduce hemodialysis related catheter infections $(27,28)$. We observed that anatomical site hygiene was more important in this region. This is especially in overweight patients, specifically as the duration of catheter use was increased, catheter-related infection rates were higher, especially irrespective of the clinic status, due to the high infection rate in the femoral vein due to thrombosis because of the catheter. We thought it facilitated the formation of infection. In our study, we found that the rates of infection were higher in patient groups in whom femoral veins were preferred compared to other access routes and were statistically significant. While removal of an infected catheter has long been considered the only way to eliminate bloodstream infection, the lack of vascular access sites in hemodialysis patients has encouraged catheter salvage and preservation of the vascular access site. Treatment is initiated with empirical antibiotics usually based on the prevalence of organisms in the dialysis unit or healthcare facility. It has been 
mentioned in several publications that early replacement of the catheter with a guide reduces the progression of infection in catheter-related infections $(29,30)$.

In our study, catheter-related infection was mostly seen in the femoral region and it was statistically significant. We ensured the continuity of their treatment by providing a new dialysis method with catheter replacement under antibiotic treatment in patients with high acute phase reactants and patients with positive blood culture. In addition, patency rates were best in the jugular, subclavian, and femoral region catheters, respectively.

\section{CONCLUSION}

In patients with chronic renal failure who need hemodialysis, jugular vein catheterization seems to be the first choice for tunneled hemodialysis catheter choice. When infection rates and patency rates were taken into consideration, other venous routes should be preferred in the presence of infection and catheter incompatibility at jugular site.

Ethics Committee Approval: The study was approved by the Ethics Committee of Selçuk University Faculty of Medicine (07.01.2014, 1/16).

Conflict of Interest: None declared by the authors.

Financial Disclosure: None declared by the authors.

Acknowledgements: None declared by the authors.

Author Contributions: Idea/Concept: ANE, OGK, OTD; Design: ANE, OGK; Data Collection/Processing: ANE, MK; Analysis/Interpretation: OGK, MK; Literature Review: ANE, OGK; Drafting/Writing: ANE; Critical Review: OGK, OTD.

\section{REFERENCES}

1. Kramer A, Stel V, Zoccali C, Heaf J, Ansell D, Grönhagen-Riska C, et al. An update on renal replacement therapy in Europe: ERA-EDTA Registry data from 1997 to 2006. Neprol Dial Transplant. 2009;24(12):3557-66.

2. Vascular Access Work Group. Clinical practice guidelines for vascular access. Guideline 7. Prevention and treatment of catheter and port complications. Am J Kidney Dis. 2006;48(Suppl 1):S248-73.

3. Lok CE, Huber TS, Lee T, Shenoy S, Yevzlin AS, Abreo K, et al. KDOQI clinical practice guideline for vascular access: 2019 update. Am J Kidney Dis. 2020;75(4 Suppl 2):S1-S164.

4. Funaki B. Central venous access: A primer for the diagnostic radiologist. Am J Roentgenol. 2002;179(2):309-18.

5. Swartz RD, Messana JM, Boyer CJ, Lunde NM, Weitzel WF, Hartman TL. Successful use of cuffed central venous hemodialysis catheters inserted percutaneously. J Am Soc Nephrol. 1994;4(9):1719-25.

6. Marr KA, Sexton DJ, Conlon PJ, Corey GR, Schwab SJ, Kirkland KB. Catheter-related bacteremia and outcome of attempted catheter salvage in patients undergoing hemodialysis. Ann Intern Med. 1997;127(4):275-80.

7. Adar R, Mozes M. Fatal complications of central venous catheters. Br Med J. 1971;3(5777):746.

8. Allon M, Brouwer-Maier DJ, Abreo K, Baskin KM, Bregel K, Chand DH, et al. Recommended clinical trial endpoints for dialysis catheters. Clin J Am Soc Nephrol. 2018;13(3):495-500.

9. Tsotsolis N, Tsirgogianni K, Kioumis I, Pitsiou G, Baka S, Papaiwannou A, et al. Pneumothorax as a complication of central venous catheter insertion. Ann Transl Med. 2015;3(3):40.

10. Peng HC, Lin SM, Wu YS, Chang WK, Sung CS, Chan $\mathrm{KH}$. Transesophageal echocardiography for diagnosis of acute hemothorax during the insertion of hemodialysis catheter. Acta Anestesiol Taiwan. 2007;45(3):181-4.

11. Kusminsky RE. Complications of central venous catheterization. J Am Coll Surg. 2007;204(4):681-96.

12. Eisen LA, Narasimhan M, Berger JS, Mayo PH, Rosen MJ, Schneider RF. Mechanical complications of central venous catheters. J Intensive Care Med. 2006;21(1):40-6.

13. Laronga C, Meric F, Truong MT, Mayfield C, Mansfield P. A treatment algorithm for pneumothoraces complicating central venous catheter insertion. Am J Surg. 2000;180(6):523-7.

14. Vats HS. Complications of catheters: tunneled and nontunneled. Adv Chronic Kidney Dis. 2012;19(3):188-94.

15. Bhutta ST, Culp WC. Evaluation and management of central venous access complications. Tech Vasc Interv Radiol. 2011;14(4):217-24.

16. Valji K. Vascular and interventional radiology. 2nd ed. Edinburgh: Elsevier Saunders, 2006.

17. Schummer W, Schummer C, Rose N, Niesen WD, Sakka SG. Mechanical complications and malpositions of central venous cannulations by experienced operators. A prospective study of 1794 catheterizations in critically ill patients. Intensive Care Med. 2007;33(6):1055-9.

18. Roldan CJ, Paniagua L. Central venous catheter intravascular malpositioning: Causes, prevention, diagnosis, and correction. West $\mathbf{J}$ Emerg Med. 2015;16(5):658-64.

19. Liberek T, Świąder W, Koprowski A, Baścik B, Dębska-Ślizień A. Tunnelled haemodialysis catheter insertion into the persistent left superior vena cava. J Vasc Access. 2020; [Epub ahead of print]. doi: $10.1177 / 1129729820933529$.

20. Webb JG, Simmonds SD, Chan-Yan C. Central venous catheter malposition presenting as chest pain. Chest. 1986;89(2):309-12.

21. Gibson F, Bodenham A. Misplaced central venous catheters: applied anatomy and practical management. Br J Anaesth. 2013;110(3):333-46.

22. Nayeemuddin M, Pherwani AD, Asquith JR. Imaging and management of complications of central venous catheters. Clin Radiol. 2013;68(5):529-44.

23. Allon M. Current management of vascular access. Clin J Am Soc Nephrol. 2007;2(4):786-800.

24. Yevzlin AS, Sanchez RJ, Hiatt JG, Washington MH, Wakeen M, Hofmann RM, et al. Concentrated heparin 
lock is associated with major bleeding complications after tunneled hemodialysis catheter placement. Semin Dial. 2007;20(4):351-4.

25. Garnacho-Montero J, Aldabó-Pallás T, PalomarMartínez M, Vallés J, Almirante B, Garcés R, et al. Risk factors and prognosis of catheter-related bloodstream infection in critically ill patients: a multicenter study. Intensive Care Med. 2008;34(12):2185-93.

26. Allon M. Dialysis catheter-related bacteremia: treatment and prophylaxis. Am J Kidney Dis. 2004;44(5):779-91.

27. Lok CE, Stanley KE, Hux JE, Richardson R, Tobe SW, Conly J. Hemodialysis infection prevention with polysporin ointment. J Am Soc Nephrol. 2003;14(1):169-79.

28. Ashby DR, Power A, Singh S, Choi P, Taube DH, Duncan ND, et al. Bacteremia associated with tunneled hemodialysis catheters: outcome after attempted salvage. Clin J Am Soc Nephrol. 2009;4(10):1601-5.

29. Saad TF. Bacteremia associated with tunelled, cuffed hemodialysis catheters. Am J Kidney Dis. 1999;34(6):1114-24.

30. Robinson D, Suhocki P, Schwab SJ. Treatment of infected tunelled venous access hemodialysis catheters with guidewire exchange. Kidney Int. 1998;53(6):1792-4. 